\title{
Cardiac lymphangioma
}

\author{
Andrzej Biskupski ${ }^{1}$, Szymon Waligórski ${ }^{1}$, Krzysztof Mokrzycki ${ }^{1}$, Mariusz Listewnik ${ }^{1}, K^{2}$ laudia Biskupska ${ }^{1}$, \\ Andrzej Kram², Wenancjusz Domagała², Mirosław Brykczyński ${ }^{1}$
}

${ }^{1}$ Department of Cardiac Surgery of Pomeranian Medical University, Szczecin, Poland

${ }^{2}$ Department of Pathology of Pomeranian Medical University, Szczecin, Poland

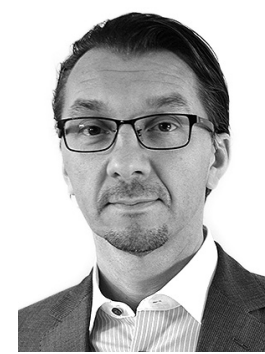

Kardiochirurgia i Torakochirurgia Polska 2013; 10 (3): 283-288

\begin{abstract}
Lymphangioma is a very rare primary tumor of the heart. It is usually incidentally found during autopsies and there have only been a handful of documented cases of this tumor in the heart. In 5 cases, it was discovered accidentally and the remaining cases gave clinical symptoms. Major symptoms of heart lymphangiomas include compression of surrounding mediastinal structures and/or inadequate blood flow through the heart. Specifically the cardiac disturbances lead to rhythm and circulatory failure. The most useful diagnostic tests for this heart tumor include echocardiography, which shows not only the tumor but also its hemodynamic effects. The following article presents the accidental finding of a lymphangioma, localized in the right atrium. It caused considerable difficulty for the blood flow into the right heart chamber, which then led to circulatory failure. In addition we will also discuss all known cases of cardiac lymphangiomas.

Key words: cardiac tumor, echocardiography, surgery.
\end{abstract}

\section{Streszczenie}

Lymphangioma to bardzo rzadki, pierwotny nowotwór serca. Rozpoznawany jest zwykle przypadkowo w badaniach autopsyjnych. Do tej pory wydano zaledwie kilkanaście publikacji dotyczących tego nowotworu. W pięciu przypadkach rozpoznano go przypadkowo, w pozostałych dawał objawy kliniczne. Wynikały one z ucisku na struktury serca lub z zaburzonego przepływu krwi przez serce. Najczęściej były to objawy niewydolności krążenia i zaburzenia rytmu serca. W diagnostyce najbardziej przydatne jest badanie echokardiograficzne przezklatkowe i przezprzełykowe (TTE, TEE), które obrazuje guz wraz z efektem hemodynamicznym. Ostateczne rozpoznanie ustalane jest zwykle na podstawie badania histopatologicznego preparatu po jego operacyjnym usunięciu. Leczeniem z wyboru jest chirurgiczne wycięcie guza. W pracy przedstawiono przypadek lymphangioma, który był zlokalizowany w świetle prawego przedsionka i powodował znaczne utrudnienie napływu krwi do prawej komory, co było przyczyną niewydolności krążenia. Omówiono także wszystkie znane opisy przypadków tego nowotworu, które dotyczyły serca.

Słowa kluczowe: guz serca, echokardiografia, operacja.

ing $20 \%$ of the heart tumors that require surgical management are recurring tumors, metastases or infiltrations [3]. The symptoms these tumors produce are determined by their localization, size, mobility, and consistency. Amongst the most common major symptoms are circulatory failure with dyspnea, palpitations, chest pain, cardiac tamponade and thromboembolic complications which can lead to stroke. Diagnostic methods most commonly used include transthoracic echocardiography (TTE), transesophageal echocardiography (TEE), magnetic resonance imaging (MRI) and computed tomography $(\mathrm{CT})$. The ideal treatment for primary heart tumors is surgical removal but in inoperable cases heart transplantation may have to be considered [4-9].

Address for correspondence: Andrzej Biskupski, Department of Cardiac Surgery, Pomeranian Medical University, Al. Powstańców Wielkopolskich 72, 70-111 Szczecin, Poland, phone: +48 9146613 91, fax: +48 9146613 93, e-mail: a.biskupski@vp.pl 
Our case involved a rare tumor of the heart, which arose from the lymphatic system, a lymphangioma. From the basis of autopsy findings of primary heart tumors, lymphangiomas only compromise $0.5 \%$ [10].

In addition, the literature has discussed 17 cases of lymphangiomas localized in the heart [11-27]. From these cases, 2 cases were diagnosed as a mixed hemolymphangioma. In the following section, we present our own incident of a patient who was diagnosed with a lymphangioma in the lumen of the right atrium (Table I).

\section{Case report}

A 66-year-old female patient was urgently referred for cardiac surgery due to a heart tumor in the right atrium. The tumor was impairing the tricuspid valve leading to disrupted blood flow into the right ventricle. The patient's history also revealed exertional dyspnea which was getting worse over the past three months and became the reason for the hospitalization in the cardiology unit. Her past medical history included arterial hypertension, thyroidectomy, and a hysterectomy. At admission, the patient was conscious, breathing adequately, and presented with symptoms of circulatory insufficiency (NYHA, class III/IV). Her physical examination did not reveal any abnormalities. She weighed $88 \mathrm{~kg}$ and was $168 \mathrm{~cm}$ in height. Blood morphology, blood clotting tests and biochemical tests were within normal limits. The CRP was $3.4 \mathrm{mg} / \mathrm{l}$. In addition, her EKG was normal. Her coronary angiography did not show any changes of the coronary arteries.

However, transthoracic echocardiography did show a right atrium increased in size with a normal sized left atrium $(31 \mathrm{~mm})$ and left ventricle $(46 \mathrm{~mm})$. The aortic and mitral valve did not show any changes. In the tricuspid outlet there was a thin-walled, weakly echogenic, cyst-like mass attached through a peduncle to the middle part of the interatrial septum. The mass caused turbulent blood flow to the right ventricle as well as mild tricuspid regurgitation with increased pressure in the right ventricle (45 $\mathrm{mm} \mathrm{Hg}$, the gradient between the right ventricle and the right atrium was $30 \mathrm{~mm} \mathrm{Hg}$ ). On the basis of the size of the right atrium, the size of the inferior vena cava, and the breathing "rate" the pressure in the right atrium was assessed to be $15 \mathrm{~mm} \mathrm{Hg}$. Also, the tricuspid annulus was dilated to $43 \mathrm{~mm}$, and had a normal systolic motion (TAPSE $18 \mathrm{~mm}$ ). In the analysis of the pulmonary flow, attention was drawn to the abnormal "dicrotic notch" with a normal ACT of 96 ms. Overall, the muscle of the left chamber was of normal thickness with good contractility. However, there was a discrete flattening of the motion of amplitude of the interventricular septum because of a right ventricular pressure overload.

Transesophageal echocardiography confirmed the presence of a thin-walled, cyst-like tumor measuring $4.5 \times 5.5 \mathrm{~cm}$. The tumor was protruding into the tricuspid outlet but the interatrial septum was not disrupted and no thrombi were seen in the left chambers of the heart. In addition, no pathology was seen in the thoracic aorta (Figs. 1 and 2).
Our patient was transferred the same day from the cardiology ward to the Department of Cardiac Surgery of the Pomeranian Medical University. To remove the mass, a median sternotomy approach with extracorporeal circulation with crystalloid cardioplegia to arrest the heart was used. The typical cannulation of the aorta and both main veins was employed, the right atrium was opened and the cyst-like mass and peduncle which was fastened to the atrial septum in the area of the foramen ovale were excised. Annuloplasty of the tricuspid valve was also performed with a $32 \mathrm{~mm}$ Edwards MC3 ring. Upon removal of the extracorporeal circulation a TEE examination to evaluate the result of the operation was performed and it showed a competent tricuspid valve after the annuloplasty as well as intact interatrial septum. The post-surgical recovery was uneventful.

The macroscopic examination of the surgical sample revealed a uniformly thin-walled, multicystic lesion measuring $4.5 \times 5.5 \mathrm{~cm}$ in its largest dimension, with a smooth external surface and light yellow serous content (Fig. 3). On the cut surface there was a larger cystic space with smaller ones dispersed in a focally thick fibrotic wall. Microscopic and histopathological examination of the cystic wall showed loose connective tissue with a few inflammatory cells, mainly lymphocytes, and many dilated lymph channels of varying sizes. These endothelial lined lymph channels (Figs. 4A and $5 A)$ showed immunohistochemical reactivity to anti-CD31 antigen (Figs. 4B and 5B).

\section{Discussion}

Lymphangioma is a benign tumor, which arises from lymphatic vessels. Redenbacker first described it in 1828. Similarly to hemangiomas, lymphangiomas are divided into 1) capillary, or simple (lymphangioma simplex, capillary lymphangioma), 2) cavernous lymphangiomas, and 3) cystic lymphangiomas (cystic hygromas). These are all soft spongy tumors, which are grey or white in color. Lymphangiomas are rarer than hemangiomas. In the literature, cases have also been documented of mixed hemolymphangiomas. Lymphangiomas may be congenital or acquired, resulting from lymphostasis, inflammation or trauma. They are most common in children. They usually occur in the head, neck, underarm and groin region, and are most common in skin tissue, mucosal membranes and soft tissue. Rarely do they occur in internal organs. About 1\% of all lymphatic tumors occur in the chest; the heart is a particularly rare site $[28,29]$. The first time a heart lymphangioma was described was in 1911, by Armstrong [11].

On the basis of 17 published and current cases the characteristics and location of heart lymphangiomas were analyzed. Ten out of eighteen cases of heart lymphangiomas occurred in adults, and more than half were found in females. Of the presented cases two were diagnosed as hemolymphangioma. One hemolymphangioma was found in the pericardium of an adult, whereas the second was found near the atrioventricular node and was the cause of death of 
Tab. I. Lymphangiomas localized in the heart (review literature)

\begin{tabular}{|c|c|c|c|c|c|c|c|c|c|}
\hline No. & Study & Age & Sex & Symptom & Localisation & Diagnosis & Treatment & Prognosis & $\begin{array}{l}\text { Cause } \\
\text { of death }\end{array}$ \\
\hline 1 & $\begin{array}{l}\text { Armstrong } \\
\text { (1911) }\end{array}$ & $5 \mathrm{yr}$ & $M$ & arrhythmia & myocardium & autopsy & - & Death & A-V Block \\
\hline 2 & $\begin{array}{l}\text { Lymburner } \\
\text { (1934) }\end{array}$ & $\begin{array}{l}10 \\
\text { mo }\end{array}$ & $M$ & $\begin{array}{l}\text { asymptomatic, } \\
\text { incidentally }\end{array}$ & $\begin{array}{l}\text { right atrial wall, } \\
\text { additional separate } \\
\text { lymphangioma: neck, } \\
\text { mediastinum }\end{array}$ & autopsy & - & Death & $\begin{array}{l}\text { Malnutri- } \\
\text { tion }\end{array}$ \\
\hline 3 & $\begin{array}{l}\text { Anbe } \\
(1973)\end{array}$ & $43 \mathrm{yr}$ & $M$ & $\begin{array}{l}\text { palpitations, } \\
\text { chest pain }\end{array}$ & both atrial walls & autopsy & - & Death & $\begin{array}{l}\text { Cardiac ar- } \\
\text { rest during } \\
\text { coronary } \\
\text { angiogra- } \\
\text { phy }\end{array}$ \\
\hline 4 & $\begin{array}{l}\text { Pasaoglu } \\
(1985)\end{array}$ & $10 \mathrm{yr}$ & $M$ & asymptomatic & $\begin{array}{l}\text { left atrial wall, } \\
\text { additional separate lym- } \\
\text { phangioma: neck, axillar } \\
\text { fossa, scapular region, }\end{array}$ & $\begin{array}{l}\text { RTG, TTE, } \\
\text { cardiac } \\
\text { catheteri- } \\
\text { zation }\end{array}$ & $\begin{array}{l}\text { median sterno- } \\
\text { tomy, complete } \\
\text { resection with } \\
\text { CPB }\end{array}$ & Alive & - \\
\hline 5 & $\begin{array}{l}\text { Nataf P } \\
(1988)\end{array}$ & adult & & palpitations & $\begin{array}{l}\text { pericardial, } \\
\text { haemolimphangioma }\end{array}$ & $\begin{array}{l}\text { RTG, TTE, } \\
\text { CT, cardiac } \\
\text { catheteri- } \\
\text { zation }\end{array}$ & $\begin{array}{c}\text { complete resec- } \\
\text { tion }\end{array}$ & Alive & - \\
\hline 6 & $\begin{array}{l}\text { Fontaliran F } \\
\text { (1989) }\end{array}$ & $0 d$ & & $\begin{array}{c}\text { congenital } \\
\text { atrioventricular } \\
\text { block }\end{array}$ & $\begin{array}{l}\text { haemolimphangioma, } \\
\text { atrioventricular node }\end{array}$ & autopsy & - & Death & A-V Block \\
\hline 7 & $\begin{array}{l}\text { Walker WP } \\
(1990)\end{array}$ & $0 \mathrm{~d}$ & $\mathrm{~F}$ & stillborn & ventricule wall & autopsy & - & Death & - \\
\hline 8 & $\begin{array}{l}\text { Daubeney } \\
\text { PEF } \\
(1996)\end{array}$ & $0 \mathrm{~d}$ & $M$ & $\begin{array}{c}\text { cardiac tampo- } \\
\text { nade }\end{array}$ & $\begin{array}{l}\text { pericardial, } \\
\text { right atrial wall, mi- } \\
\text { micking a mediastinal } \\
\text { tumour }\end{array}$ & TTE, MRI & $\begin{array}{l}\text { pericardial } \\
\text { window }\end{array}$ & Alive & - \\
\hline 9 & $\begin{array}{l}\text { Jougon J } \\
(2002)\end{array}$ & 67 & $\mathrm{~F}$ & dyspnea & $\begin{array}{l}\text { pericardial, } \\
\text { left atrial wall, mimic- } \\
\text { king a mediastinal } \\
\text { tumour }\end{array}$ & RTG, MRI & $\begin{array}{l}\text { median sterno- } \\
\text { tomy, complete } \\
\text { resection with } \\
\text { CPB after } \\
\text { transection of } \\
\text { the aorta and } \\
\text { pulmonary } \\
\text { trunk }\end{array}$ & Alive & - \\
\hline 10 & $\begin{array}{l}\text { Kaji T } \\
(2002)\end{array}$ & 6 & $\mathrm{~F}$ & $\begin{array}{l}\text { asymptomatic, } \\
\text { incidentally }\end{array}$ & $\begin{array}{l}\text { pericardial, } \\
\text { left ventricule wall, } \\
\text { mimicking a mediastinal } \\
\text { tumour }\end{array}$ & $\begin{array}{l}\text { TTE, CT, } \\
\text { MRI }\end{array}$ & $\begin{array}{l}\text { thoracotomy, } \\
\text { partial resection } \\
\text { and pericardial } \\
\text { window }\end{array}$ & Alive & - \\
\hline 11 & $\begin{array}{l}\text { Flörchin- } \\
\text { ger B } \\
(2005)\end{array}$ & 62 & $\mathrm{~F}$ & $\begin{array}{c}\text { dyspnea, palpi- } \\
\text { tations }\end{array}$ & $\begin{array}{l}\text { intracardiac } \\
\text { mitral valve, anterior } \\
\text { leaflet, } \\
\text { intraventricular lym- } \\
\text { phangioma }\end{array}$ & TTE & $\begin{array}{l}\text { median sterno- } \\
\text { tomy, complete } \\
\text { resection with } \\
\text { CPB and recon- } \\
\text { struction mitral } \\
\text { valve }\end{array}$ & Alive & - \\
\hline 12 & $\begin{array}{l}\text { Pennec PY } \\
(2006)\end{array}$ & 21 & $\mathrm{~F}$ & palpitations & left ventricule wall & $\begin{array}{l}\text { TTE, MRI, } \\
\text { biopsy }\end{array}$ & $\begin{array}{c}\text { cardioverter } \\
\text { defibrillator } \\
\text { was implanted } \\
\text { and next heart } \\
\text { transplant }\end{array}$ & Alive & - \\
\hline 13 & $\begin{array}{l}\text { Kim SJ } \\
(2007)\end{array}$ & 44 & $\mathrm{~F}$ & $\begin{array}{l}\text { asymptomatic, } \\
\text { incidentally }\end{array}$ & $\begin{array}{l}\text { intracardiac } \\
\text { right atrial septum, } \\
\text { cystic mass in right } \\
\text { atrium, intraatrial lym- } \\
\text { phangioma }\end{array}$ & $\begin{array}{l}\text { TTE, TEE, } \\
\text { CT }\end{array}$ & $\begin{array}{l}\text { median sterno- } \\
\text { tomy, complete } \\
\text { resection with } \\
\text { CPB }\end{array}$ & Alive & - \\
\hline 14 & $\begin{array}{l}\mathrm{Naz} \text { I } \\
(2009)\end{array}$ & 32 & $\mathrm{~F}$ & dyspnea & $\begin{array}{l}\text { pericardial, } \\
\text { right ventricle and right } \\
\text { atrium wall, } \\
\text { mimicking a mediastinal } \\
\text { tumour }\end{array}$ & $\begin{array}{l}\text { TTE, TEE, } \\
\text { CT, MRI }\end{array}$ & $\begin{array}{l}\text { median sterno- } \\
\text { tomy, complete } \\
\text { resection with } \\
\text { CPB }\end{array}$ & Alive & - \\
\hline
\end{tabular}


Tab. I. Cont.

\begin{tabular}{|c|c|c|c|c|c|c|c|c|c|}
\hline No. & Study & Age & Sex & Symptom & Localisation & Diagnosis & Treatment & Prognosis & $\begin{array}{l}\text { Cause } \\
\text { of death }\end{array}$ \\
\hline 15 & $\begin{array}{l}\text { Kim DH } \\
(2010)\end{array}$ & 38 & $F$ & $\begin{array}{l}\text { cough and } \\
\text { dyspnea }\end{array}$ & $\begin{array}{l}\text { intracardiac } \\
\text { intraatrial and intraven- } \\
\text { tricular lymphangiomas }\end{array}$ & TTE, CT & $\begin{array}{l}\text { median sterno- } \\
\text { tomy, complete } \\
\text { resection with } \\
\text { CPB }\end{array}$ & Alive & - \\
\hline 16 & $\begin{array}{l}\text { Zakaria RH } \\
\text { (2011), } \\
\text { Almarsafa- } \\
\text { wy H (2011) }\end{array}$ & 1 & M & $\begin{array}{l}\text { respiratory } \\
\text { distress }\end{array}$ & $\begin{array}{l}\text { pericardial, } \\
\text { right atrial wall, mi- } \\
\text { micking a mediastinal } \\
\text { tumour }\end{array}$ & $\mathrm{CT}, \mathrm{MRI}$ & $\begin{array}{l}\text { median sterno- } \\
\text { tomy, complete } \\
\text { resection with } \\
\text { CPB } \\
\end{array}$ & Alive & - \\
\hline 17 & $\begin{array}{l}\text { Shroff } \\
\text { (2011) }\end{array}$ & 58 & $\mathrm{~F}$ & $\begin{array}{l}\text { asymptomatic, } \\
\text { incidentally }\end{array}$ & $\begin{array}{l}\text { pericardial, interventri- } \\
\text { cular groove, } \\
\text { mimicking a mediastinal } \\
\text { tumour }\end{array}$ & $\begin{array}{l}\text { RTG, CT, } \\
\text { TEE }\end{array}$ & $\begin{array}{l}\text { median sterno- } \\
\text { tomy, complete } \\
\text { resection witho- } \\
\text { ut CPB }\end{array}$ & Alive & - \\
\hline 18 & $\begin{array}{l}\text { Biskupski } \\
(2012)\end{array}$ & 66 & $\mathrm{~F}$ & dyspnea & $\begin{array}{l}\text { intracardiac } \\
\text { right atrial septum, } \\
\text { cystic mass in right } \\
\text { atrium, } \\
\text { intraatrial lymphan- } \\
\text { gioma }\end{array}$ & TTE, TEE & $\begin{array}{l}\text { median sterno- } \\
\text { tomy, complete } \\
\text { resection with } \\
\text { CPB, } \\
\text { tricuspidal valve } \\
\text { plastic }\end{array}$ & Alive & - \\
\hline
\end{tabular}

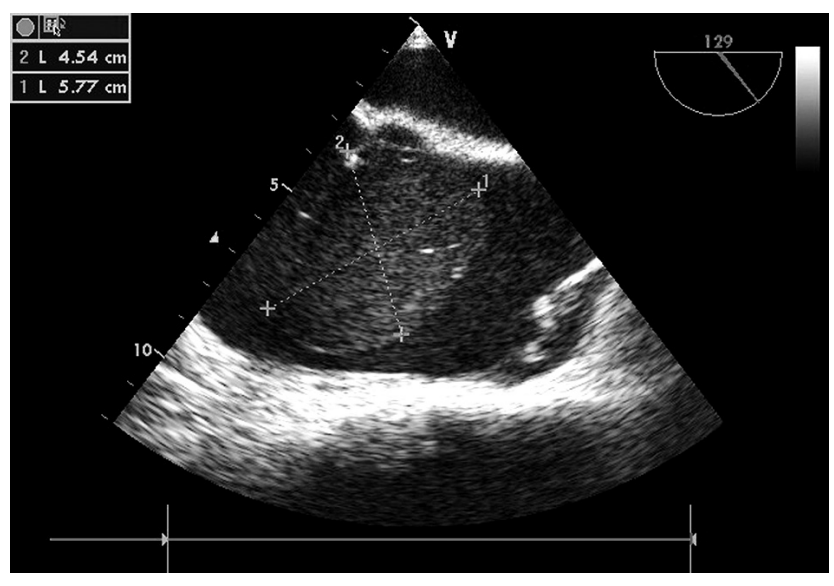

Fig. 1. Transesophageal echocardiography: size of the tumor in the right atrium

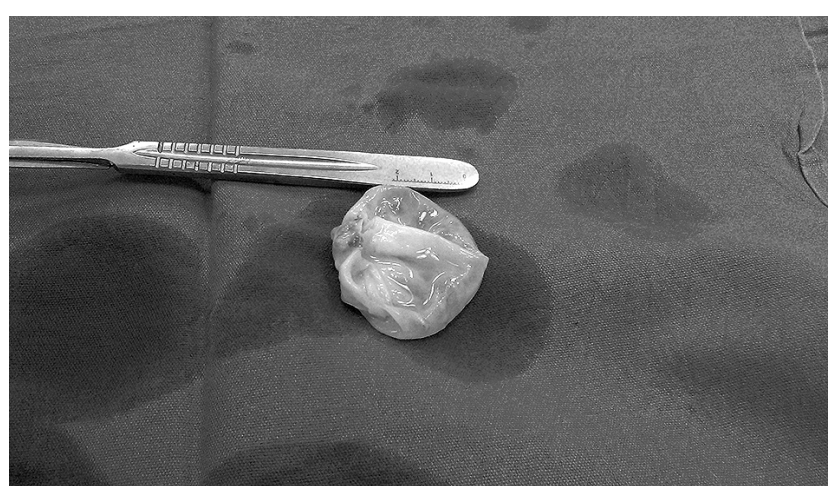

Fig. 3. Macroscopic view of the removed tumor

a newborn because it led to atrioventricular congenital block $[13,14]$. Of the remaining cases, seven lymphangiomas grew within the pericardium, in another six cases the growth was mainly localized to the atrium or ventricle, and in the re-

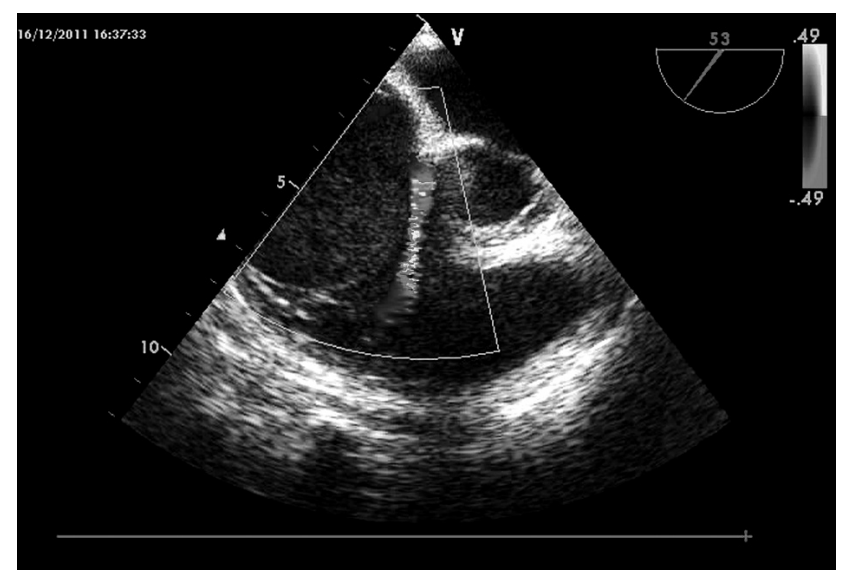

Fig. 2. Transesophageal echocardiography: turbulent blood flow around the tumor in the right atrium

maining four cases the cyst-like tumors grew into the heart cavity. In one of these cases the tumor grew into the mitral valve [20].

Current literature cases have also described the symptoms of lymphangiomas. In five cases the changes were without symptoms and were discovered incidentally. The symptoms that were produced by the tumors were based on the tumor size, location, and mobility. Symptoms occurred due to compression of the neighboring structures, from the decrease of circulating blood, and/or from dysfunction of the heart valves. The most common symptoms were dyspnea in six cases, palpitations in six cases, chest pain in one case, and effusion into the pericardium, which manifested as heart tamponade, in one case. In two cases an atrioventricular conduction block was the cause of death. Unfortunately, in one patient cardiac arrest occurred during catheterization. In another two cases the tumor caused heart valve dysfunction. 

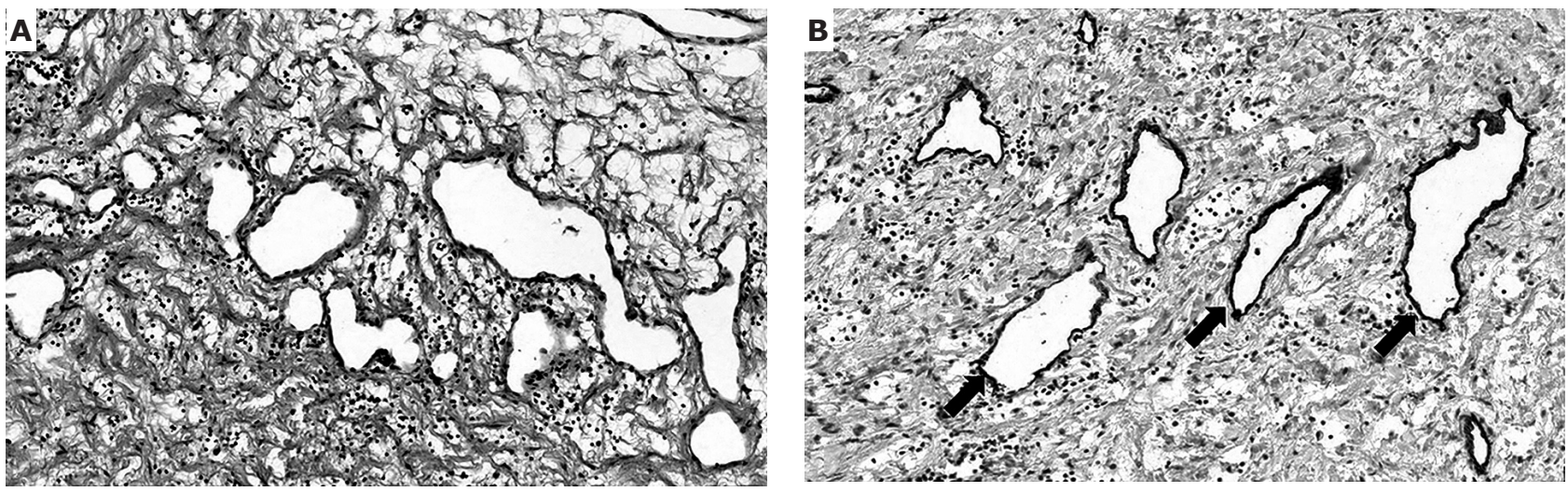

Fig. 4. A) Histology of cystic wall with loose connective tissue containing many small and medium sized lymph channels and few scattered lymphocytes between them. HE staining, original magnification $\times 200$. B) Endothelial lining (arrows) with immunohistochemical reactivity to anti-CD31 antigen. Immunohistochemical staining, original magnification $\times 200$
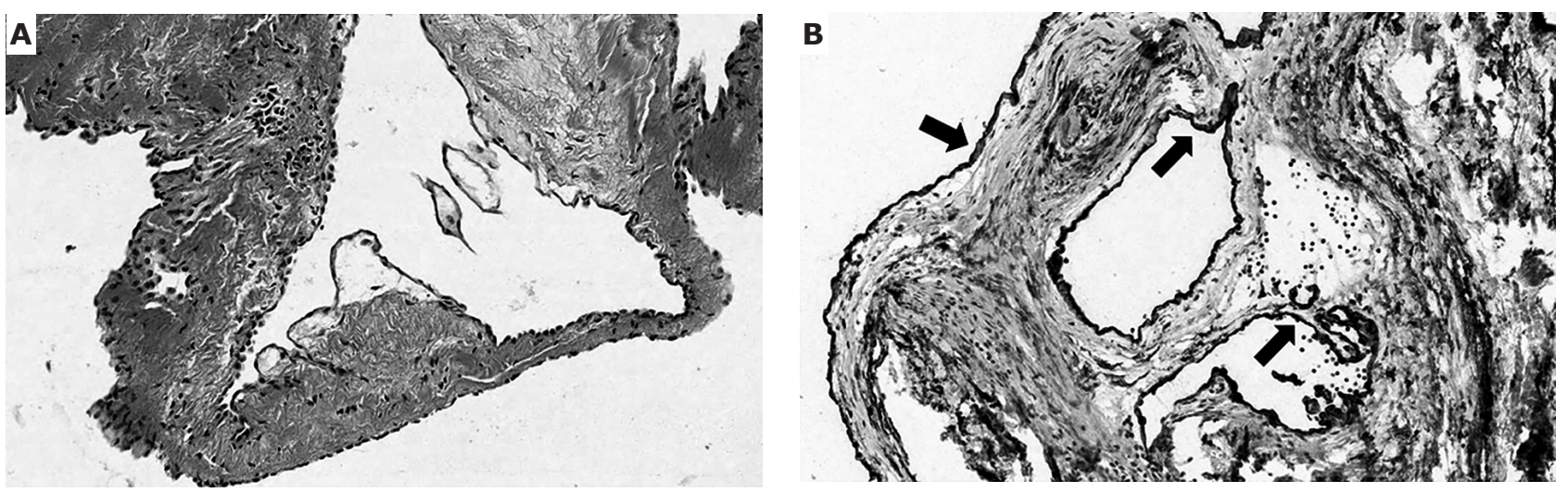

Fig. 5. A) Histology of cystic wall with loose connective tissue containing large lymph channels and few scattered lymphocytes. HE staining, original magnification $\times 200$. B) Endothelial lining (arrows) with immunohistochemical reactivity to anti-CD31 antigen. Immunohistochemical staining, original magnification $\times 200$

In the case of a lymphangioma that was growing into the anterior leaflet of the mitral valve, there was insufficient closure of the valve during systole. Hence, after tumor removal an annuloplasty to fix the valve was needed. Our case of the 66-year-old female patient also involved valve dysfunction because the tumor protruded through the right atrium via the tricuspid valve into the right ventricle. This caused a significantly limited influx of blood into the right ventricle with a moderate wave of regurgitation through the tricuspid valve. After the tumor's removal, annuloplasty of the tricuspid valve with ring implantation was performed. This blockage of blood flow between the atrium and ventricle by the atrial tumor caused hemodynamic instability. In fact, this is the most common cause of severe symptoms and the most common cause of sudden cardiac death, which is why patients must be operated on quickly.

It is worth mentioning that three patients from the published lymphangioma cases had a coexisting tumor in a different location in addition to the heart tumor. In the first case the extra tumor was found in the neck and chest region, in the second the neck, armpits, and shoulder blade region, and in the third the tumor occurred in the pelvis.
Different diagnostic methods have also been used in the numerous lymphangioma cases. For example, the final diagnosis was confirmed by autopsy findings (in five cases) and after the tumor was removed (in twelve cases) only in one case was the diagnosis confirmed before tumor removal with the help of a biopsy [21]. In our opinion echocardiography (TEE and TTE) is the most useful imaging technique to localize heart tumors; it also makes it possible to evaluate the shape, size, mobility and integration of the tumor with the surrounding heart structures. In addition, this procedure is fast and can be performed at the patients' bedside.

The preferred removal technique is surgical, through a sternotomy. In the majority of the heart tumor removals, a sternotomy with extracorporeal circulation was used. Even though there was no case of a lymphangioma being removed through a minithoracotomy, this is a good alternative due to its minimally invasive technique [30, 31]. Lastly, it is important to remove the whole tumor as incomplete removal may lead to localized recurrence [32].

\section{References}

1. Kirklin JW, Barratt-Boyes BG. Cardiac surgery. $3^{\text {rd }}$ ed. Churchill Livingstone, New York 2003; p. 1680. 
2. Maruszewski B. KROK, Krajowy Rejestr Operacji Kardiochirurgicznych w Polsce. Kardiochir Torakochir Pol 2012; 2: 283-287.

3. Burke A, Virmani R. Tumors of the heart and great vessels. In: Atlas of tumor pathology. Armed Forces Institute of Pathology, Washington 1996.

4. Odim J, Reehal V, Laks H, Mehta U, Fishbein M. Surgical pathology of cardiac tumors: Two decades at an urban institution. Cardiovasc Pathol 2003; 12 : 267-270

5. Vander Salm TJ. Unusual primary tumors of the heart. Semin Thorac Cardiovasc Surg 2000; 12: 89-100.

6. Maraj S, Pressman GS, Figueredo VM. Primary cardiac tumors. Int J Cardiol 2009; 133: 152-156.

7. Butany J, Nair V, Naseemuddin A, Nair GM, Catton C, Yau T. Cardiac tumours: diagnosis and management. Lancet Oncol 2005; 6: 219-228.

8. Centofanti P, DiRosa E, Deorsola L, Centofanti P, DiRosa E, Deorsola L, Dato GM, Patanè F, La Torre M, Barbato L, Verzini A, Fortunato G, di Summa M. Primary cardiac tumors: early and late results of surgical treatment In 91 patients. Ann Thorac Surg 1999; 68: 1236-1241.

9. Grebenc M, Rosado de Christenson M, Burke A, Green C, Galvin J. Primary cardiac and pericardial neoplasms: radiologic-pathologic correlation. Radiographics 2000; 20: 1073-1103.

10. McAllister HA, Fenoglio JJ. Tumors of the cardiovascular system, atlas of tumor pathology, series 2. Armed Forces Institute of Pathology, Washington 1978.

11. Armstrong $\mathrm{H}$, Monckeberg JG. Herzblock bedingt durch primären Herz tumor, bei einem fünfjährigen Kind. Deutsch Arch Klin Med 1911; 102: 144-166.

12. Anbe DT, Fine G. Cardiac lymphangioma and lipoma. Report of a case of simultaneous occurrence in association with lipomatous infiltration of the myocardium and cardiac arrhythmia. Am Heart J 1973; 86: 227-235.

13. Nataf P, Mestiri T, Martin de Lasalle E, Benomar M, Gandjbakhch I, Cabrol C. Hemolymphangiome pericardique. A propos d'une observation. Arch Mal Coeur Vaiss 1988; 81: 1137-1140.

14. Fontaliran F, Guillois B, Colin A et al. Bloc auriculo-ventriculaire congenital et lupus erythemateux maternel. Decouverte histologique d'une tumeur du noeud auriculo-ventriculaire. Arch Mal Coeur Vaiss 1989; 82: 609-613.

15. Walker WP, Landas SK. Nuchal cystic hygroma associated with massive lymphangiomatosis of the upper extremity and myocardium in a stillborn fetus: a case report. Am J Cardiovasc Pathol 1990; 3: 341-346.

16. Paşaoğlu I, Doğan R, Ozme S, Pasaoglu I, Dogan R, Ozme S, Kale G, Bozer AY. Cardiac lymphangioma. Am J Heart 1991; 121: 1821-1824.

17. Daubeney PE, Ogilvie BC, Moore IE, Webber SA. Intrapericardial lymphangioma presenting as neonatal cardiac tamponade. Pediatr Cardiol 1996; 17: 129-131
18. Jougon J, Laborde MN, Parrens M, MacBride T. Cystic lymphangioma of the heart mimicking a mediastinal tumor. Eur J Cardiothorac Surg 2002; 22: 476-478.

19. Kaji T, Takamatsu H, Noguchi H, Kaji T, Takamatsu H, Noguchi H, Tahara H, Matsuda H, Nomura Y, Machigashira S, Watanabe S, Yoshioka T. Cardiac lymphangioma: case report and review of the literature. J Pediatr Surg 2002; 37: E32.

20. Flörchinger B, Rümmele $P$, Lehane $C$, Flörchinger $B$, Rümmele $P$, Lehane $C$, Schmid FX, Birnbaum DE. Mitral prolapse caused by lymphangioma. Thorac Cardiovasc Surg 2005; 53: 180-183.

21. Pennec PY, Blanc JJ. Cardiac lymphangioma: a benign cardiac tumour. Eur Heart J 2006; 27: 2913.

22. Kim SJ, Shin ES, Kim SW, Kim SJ, Shin ES, Kim SW, Shin JK, Cheong JP, Kim YM, Lee SG. A case of cardiac lymphangioma presenting as a cystic mass in the right atrium. Yonsei Med J 2007; 48: 1043-1047.

23. Naz I, Lone I. Cystic lymphangioma of heart. Internet J Pathol 2009; 10 Number 1.

24. Kim DH, Seo HS, Seo J, Kim HK, Her K, Suk EH. Lymphangiomatosis involving the inferior vena cava, heart, pulmonary artery and pelvic cavity. Korean I Radiol 2010; 11: 115-118.

25. Zakaria RH, Barsoum NR, El-Basmy AA, El-Kaffas SH. Imaging of pericardial lymphangioma. Ann Pediatr Cardiol 2011; 4: 65-67.

26. Almarsafawy H, Matter M, Elgamal MA, Zalata K. Cardiac lymphangioma in an infant. Pediatr Cardiol 2011; 32: 1253-1255.

27. Shroff GS, Lata AL, Parks GE, Entrikin DW. Giant pericardial lymphangioma - imaging, surgical, and pathologic correlations. J Comput Assist Tomogr 2011; 35: 642-644

28. Faul JL, Berry GJ, Colby TV, Ruoss SJ, Walter MBR, Rosen GD, Raffin TA. Thoracic lymphangiomas, lymphangiectasis, lymphangiomatosis, and lymphatic dysplasia syndrome. Am J Respir Crit Care Med 2000; 161: 1037-1046.

29. Hillard RI, McKendry JBJ, Phillips MJ. Congenital abnormalities of the lymphatic system: a new clinical classification. Pediatrics 1990; 86: 988-994.

30. Iribarne A, Easterwood R, Russo MJ, Yang J, Cheema FH, Smith CR, Argenziano M. Long-term outcomes with a minimally invasive approach for resec tion of cardiac masses. Ann Thorac Surg 2010; 90: 1251-1255.

31. Pineda AM, Santana O, Zamora C, Benjo AM, Lamas GA, Lamelas J. Outcomes of a minimally invasive approach compared with median sternotomy for the excision of benign cardiac masses. Ann Thorac Surg 2011; 91: 1440-1444.

32. Icard P, Le Rochais JP, Galateau F, Jehan A, Martel B, Brun J, Evrard D. Mediastinal cystic hygroma: report of three cases and review of the literature. Ann Chir 1998; 52: 629-634. 